$\stackrel{\odot}{\text { II }}$

\title{
ZACHOWANIE CZŁOWIEKA JAKO PRZEDMIOT BADAŃ PSYCHOLOGII SPOŁECZNEJ - FAKT CZY MIT?
}

\begin{abstract}
Dariusz Doliński, Zachowanie człowieka jako przedmiot badań psychologii społecznej-fakt czy mit? [Human behavior as a subject of social psychology - fact or myth?] edited by M. Obrębska, G. Dziamski, „CZłowiek i Społeczeństwo" vol. XLIX: Humanistyka jutra [Humanities of Tomorrow], Poznań 2020, pp. 167-174, Adam Mickiewicz University. ISSN 0239-3271, https://doi.org/10.14746/cis.2020.49.9.

Social psychologists only to very small degree investigate real human behavior. This article is an analysis of the reasons why this is so. The author points out that the otherwise valuable phenomenon of cognitive shift, which occurred precisely in the 1960s, naturally boosted the interest of social psychologists in such phenomena like stereotypes and values; at the same time, it unfortunately decreased interest in others, like aggression or altruism. Researchers today generally preferring to employ survey studies (even if they are a component of experiments being conducted) to analysis of behavioural variables. This gives rise to the question of whether social psychology remains a science of behavior.
\end{abstract}

Dariusz Doliński, SWPS Uniwersytet Humanistycznospołeczny, Wydział Psychologii, ul. Ostrowskiego 30B, 53-238 Wrocław, e-mail: ddolinsk@swps.edu.pl, ORICD: https://orcid. org/0000-0002-4225-4258.

Wybuch skandalu związanego z naukowymi oszustwami popełnionymi przez Diederika Stapela spowodował w środowisku psychologów społecznych pojawienie się wielu nadzwyczaj ważnych inicjatyw mających zapobiec kryzysowi tej dyscypliny wiedzy. Zauważono potrzebę replikacji badań, zwracania większej uwagi na parametr wielkości efektu niż na istotność różnic między średnimi, pojawiła się idea prerejestracji planowanych eksperymentów. I choć nie można jeszcze mówić o tym, że stan psychologii społecznej jest wyraźnie i jednoznacznie lepszy niż dekadę 
czy kilka dekad temu (por. Motyl i in., 2017), sama rozwijająca się debata na ten temat i rosnąca świadomość istniejących problemów są zjawiskami o fundamentalnej wadze.

Celem tego artykułu jest zwrócenie uwagi na zupełnie inną kwestię, która jednak także wiąże się z kryzysem psychologii społecznej. Zanim jeszcze wybuchł skandal związany z oszustwami Stapela, na łamach Perspectives on Psychological Science ukazał się artykuł Roya Baumeistera, Kathleen Vohs i Davida Fundera (2007) pod znamiennym tytułem Psychology as the science of self reports and finger movements. Autorzy tego tekstu zwrócili uwagę na to, że choć psychologia definiowana jest jako nauka o zachowaniu, współcześnie nie ono jest głównym przedmiotem uwagi. O ile zoopsychologowie oraz psychologowie rozwojowi rzeczywiście obserwują i analizują zachowania (jak dowcipnie sugerują autorzy: być może dlatego, że nie mogą skłonić swoich badanych - zwierząt i małych, nieumiejących pisać, dzieci, do wypełniania kwestionariuszy), to w przypadku psychologii społecznej zachowania inne niż wypełnianie kwestionariuszy, uderzanie w klawisze klawiatury komputerowej czy klikanie myszką należą do rzadkości. Autorzy dokonali przeglądu najnowszego wówczas (ze stycznia 2006 roku) numeru Journal of Personality and Social Psychology (flagowego czasopisma tej dyscypliny) i stwierdzili, że ruchy palców (na klawiaturze albo trzymających ołówek czy długopis) to właściwie niemal jedyne przejawy zachowań, empirycznie eksplorowane przez psychologów społecznych.

Kilkanaście lat później postanowiłem sprawdzić, czy coś w tej materii się zmieniło (Doliński, 2018a). W odróżnieniu od Baumeistera, Vohs i Fundera zdecydowałem się jednak nie koncentrować na pojedynczym numerze czasopisma, lecz dokonać oglądu tego, co zaprezentowane jest w całym woluminie. Każdy wolumin Journal of Personality and Social Psychology składa się z 6 numerów. Analizowany przeze mnie zawierał łącznie 49 artykułów. Okazało się, że proporcja badań zachowań (innych niż odpowiadanie na pytania kwestionariusza przy użyciu klawiatury lub papieru i ołówka) do wszystkich studiów empirycznych zaprezentowanych w tych tekstach wyniosła około 6\%. Można by zapytać, czy JPSP nie jest z tej perspektywy pismem specyficznym, koncentrującym się na przykład na takich zagadnieniach jak stereotypy, uprzedzenia, postawy i wartości, co oczywiście uzasadniałoby brak zainteresowania autorów realnymi zachowaniami. Analiza zawartości innych czołowych światowych czasopism psychologicznych (Doliński, 2018b) pokazuje jednak, że awersja psychologów społecznych do badania realnych zachowań to stan niezależny od tytułu periodyku, które weźmiemy pod uwagę. Zatrważająco niski odsetek badań 
realnych zachowań dotyczy bowiem także takich tytułów jak European Journal of Social Psychology, Journal of Experimental Social Psychology, Personality and Social Psychology Bulletin czy Social Psychological and Personality Science. Mówiąc ściślej, dotyczy wszystkich tytułów, które pod tym kątem sprawdzałem.

Oczywiście pojawia się pytanie o przyczynę tak drastycznego odejścia psychologii społecznej od badania realnych zachowań. Baumeister, Vohs i Funder (2007) szacują, że w roku 1976 około 80\% tekstów w JPSP poświęconych było badaniu zachowań. Odsetek ten dziesięć lat później był już ponad trzy razy mniejszy! Potem zmniejszał się stopniowo i konsekwentnie, by w roku 2006 osiągnąć poziom kilkunastoprocentowy. Jak widzimy, dziś, praktycznie rzecz biorąc, takich badań już niemal w ogóle nie ma...

To, że odejście od badań zachowania miało miejsce w latach 70 . XX wieku, wydaje się mieć wyraźny związek z dokonującą się wtedy tak zwaną rewolucją poznawczą w psychologii społecznej (w innych obszarach psychologii, jak motywacje czy zagadnienia uczenia się, rewolucja ta dokonała się mniej więcej dekadę wcześniej). W wyjaśnianiu przyczyn ludzkich zachowań psychologowie społeczni zaczęli sięgać do wiedzy dotyczącej przetwarzania informacji, uwagi czy pamięci. Koncentracja na tym, co można raczej zmierzyć niż bezpośrednio zaobserwować, spowodowała też spadek zainteresowań psychologii pewnymi zagadnieniami, a wzrostem zainteresowania - innymi. I tak psychologowie zaczęli coraz rzadziej badać takie problemy, jak na przykład altruizm i agresję (a więc zachowania), a coraz częściej - stereotypy czy sądy o świecie społecznym (a więc przekonania).

Wydaje się także, że, niezależnie od wspomnianej rewolucji poznawczej, psychologia w ostatnich dekadach zaczęła bardziej interesować się nie samym określeniem zależności przyczynowo-skutkowych (tj. tym, kiedy pojawi się określone zachowanie), ale mechanizmami psychologicznymi, które te zachowania uruchamiają. Inaczej mówiąc, skoncentrowała się na tym, dlaczego człowiek w konkretnej sytuacji zachowuje się w określony sposób, co samo w sobie należy oceniać jednoznacznie pozytywnie. Problem wszakże w tym, że badaczowi wygodniej było w takiej sytuacji posadzić osobę badaną przy biurku, poprosić ją, by wyobraziła sobie, że coś robi (albo ma podjąć decyzję, co zrobi) i zadać jej szereg pytań, ukierunkowanych na poszukiwanie wspomnianych mechanizmów uruchamiających zachowania.

Oczywiście nie byłoby problemu, gdyby deklaracje ludzi na temat tego, jak się zachowają, pokrywały się z ich rzeczywistym zachowaniem. Istnieje 
jednak mnóstwo dowodów, że w bardzo wielu sytuacjach tak nie jest. W sondażu prowadzonym na zlecenie Deutsche Bank (2014) respondenci mieli odpowiedzieć na pytanie, na co wydaliby pięć milionów, gdyby wygrali taką sumę w grze losowej lub dostali w spadku. 27,5\% ankietowanych zadeklarowała, że znaczną jej część rozdałaby biednym. Realia pokazują tymczasem, że wygrywający niezwykle rzadko przeznaczają choćby część wygranej na cele charytatywne (Kaplan, 1987). Znaczne rozbieżności między deklaracją na temat własnego zachowania a realnym zachowaniem ujawniają także badania psychologiczne. Tomasz Grzyb (2016), dla przykładu, w badaniu poświęconym mechanizmowi rozkładu odpowiedzialności sprawdzał, jak liczba osób siedzących w przedziale kolejowym wpływała na prawdopodobieństwo, że podmiot zareaguje, gdy jeden z pasażerów okrada kobietę, która na chwilę wyszła z przedziału. Okazuje się, zgodnie z klasyczną prawidłowością psychologiczną, że badany znacznie częściej reaguje, gdy jest jedynym świadkiem kradzieży, niż w warunkach, w których świadków jest trzech. Jeśli jednak badanym tylko opisywano sytuację (niektórym w warunkach, w których są jedynymi świadkami, a innym w warunkach, w których są jednym z trzech świadków) i pytano o to, jak by się zachowali, to informacja o liczbie świadków nie miała żadnego znaczenia dla ich odpowiedzi. Przegląd badań międzykulturowych (Peng, Nisbett i Wong, 1997) pokazuje z kolei, że jeśli porównuje się ludzi żyjących w poszczególnych kulturach na podstawie ich deklaracji werbalnych, to otrzymuje się zupełnie inny obraz, niż wtedy, gdy porównuje się ich realne zachowania. Dotyczy to przy tym tak różnych obszarów życia, jak kulturalne zachowywanie się przy stole, czas spędzany na aktywności sportowej czy utrzymywanie czystości i porządku. Innym, nie mniej spektakularnym przykładem rozbieżności między tym, jak ludzie zachowują się w realnych sytuacjach, a tym, jak odpowiadają na pytanie o to, jak by się zachowali, mogą być klasyczne badania nad posłuszeństwem realizowane w paradygmacie Stanleya Milgrama (1974). Grzyb i Doliński (2007) wykazali, że nawet u ludzi, którzy znają dobrze badania Milgrama, dominuje przekonanie, że bardzo szybko, już w początkowym etapie eksperymentu, odmówiliby wykonywania poleceń eksperymentatora.

Dlaczego psychologowie społeczni nie badają realnych zachowań nawet tam, gdzie explicite deklarują w artykułach, że je badają, a w rzeczywistości tylko pytają ludzi, jak by się w określonej sytuacji zachowali? Wydaje się, że przyczyny są co najmniej dwie. Po pierwsze, badanie realnych zachowań jest znacznie trudniejsze i bardziej czaso- i pracochłonne od badania werbalnych deklaracji. Jaka jest druga przyczyna? Obserwowane 
zachowanie ma najczęściej charakter zero-jedynkowy. Ktoś przeprowadził niewidomego przez jezdnię albo tego nie zrobił. Ktoś oddał znalezione na uniwersyteckim korytarzu pióro, a ktoś inny tego nie zrobił. Ktoś wziął (albo nie) udział w wyborach, ktoś w ulicznym proteście, ktoś podpisał petycję. Ktoś inny rozmienił komuś innemu banknot na drobne albo nie, ktoś zatrzymał samochód, by udzielić pomocy nieszczęśnikowi, który swoim autem stanął na środku drogi, a ktoś inny tego nie zrobił. Kluczowe jest zatem to, czy na przykład ktoś w określonej sytuacji zachował się altruistycznie, czy nie (czy na przykład dał datek, czy nie) oraz czy w określonej sytuacji zachował się uczciwie, czy nie (na przykład czy ukradł pieniądze, czy nie). Taki dychotomiczny charakter zmiennej zależnej wyklucza jednak możliwość zastosowania wielu wyrafinowanych analiz statystycznych (albo umożliwia takie, ale wyłącznie przy dużych zbadanych próbach, co ze względu na wspomnianą wyżej pracochłonność samych badań jest nadzwyczaj kłopotliwe). Jeśli więc badacz chce, by coś „wyszło”, woli unikać zero-jedynkowej zmiennej zależnej. Problem wszakże w tym, że jeśli dopasowujemy metodę do możliwości przeprowadzenia odpowiednich analiz, a nie poszukujemy takich modeli statystycznych, które pozwolą nam zbadać rzeczywistość, to sprowadzamy wszystko do absurdu. Unikanie tego, by zmienna zależna była dychotomiczna, i takie planowanie badań, by zachowanie można było badać na skali interwałowej, jest więc sprowadzaniem do absurdu badania eksperymentalnego. To sposób analizy danych powinien być dobrany do analizowanego problemu, a nie problem określany i empirycznie operacjonalizowany tak, by wyniki dało się łatwo policzyć. Mówiąc wprost: to pies powinien machać ogonem, a nie ogon psem.

Co więcej, traktowanie przez psychologów społecznych skal pomiarowych stosowanych w badaniach psychologicznych mierzących rzekomo zachowanie, a de facto „deklarowaną skłonność do określonych zachowań”, jako skal interwałowych jest wielce problematyczne. Skala, w której zapytalibyśmy na przykład ,jaką kwotę (w złotych od 0 do 100) przeznaczyłbyś na cele dobroczynne?”, tylko pozornie jest skalą interwałową. W rzeczywistości bowiem różnica między 0 a 1 tylko matematycznie jest tym samym, co różnica między, powiedzmy, 33 a 34 . W istocie między 0 a 1 jest olbrzymia różnica jakościowa: nic vs coś - odmowa wsparcia vs zaangażowanie się. Tak samo będzie z oszukiwaniem. Oszukanie raz na dziesięć okazji jest czymś znacząco różnym od nieoszukania ani razu, a między oszukaniem sześć i oszukaniem siedem razy różnica jest de facto niewielka.

Jaki paradygmat badawczy dominuje dziś w psychologii społecznej? Jeśli przyjrzymy się tekstom z czołowych światowych periodyków, to przekonamy 
się, że jest to podejście oparte na zmierzeniu kwestionariuszami niemal wszystkiego, co z perspektywy teoretycznej wydaje się sensowne, i pokazanie wyników w postaci złożonych modeli, obfitujących w strzałki i liczby. Najlepiej, jeśli uda się przedstawić skomplikowane modele zawierające liczne mediatory i moderatory. „Bez mediacji nie ma publikacji” - mówią dziś badacze, wychodząc naprzeciw zapotrzebowaniu recenzentów i edytorów i publikują teksty z rycinami tak skomplikowanymi, że ich sensu prawie nikt nie potrafi zrozumieć.

Z dominującą dziś w psychologii społecznej metodologią badań opartą na wypełnianiu przez osoby badane baterii kwestionariuszy jest jeszcze jeden poważny problem. Oczywiście w takich warunkach mogą pojawić się artefakty wynikające z tego, że zmęczeni czy zniecierpliwieni badani zaczynają być coraz mniej uważni i coraz bardziej niestaranni. Oprócz tego, oczywistego skądinąd, problemu jest jednak inny, na który nie zwraca się uwagi, a który wydaje mi się znacznie poważniejszy.

Zgodnie z prawem nieoznaczoności Wernera Karla Heisenberga (1927) pomiar może zakłócać stan mierzonego obiektu. W odniesieniu do psychologii oznacza to, że mierząc (na przykład kwestionariuszami, rozmową czy aparaturą psychofizjologiczną) ludzkie postawy czy zachowania, zmieniamy ich przebieg. Inaczej mówiąc, ów przebieg jest inny w sytuacji, gdy go mierzymy, a inny - gdy go nie mierzymy. Prawo nieoznaczoności ma też zastosowanie w badaniach, w których najpierw prosi się ludzi o samoopis w kwestionariuszu, a następnie bada zachowanie semantycznie związane z tym samoopisem. Wyobraźmy sobie zatem, że zmienną zależną jest przejawiany przez badanych altruizm lub uczciwość (akurat w tym przypadku: wszystko jedno, czy realne, czy jedynie deklarowane), a samoopisowe kwestionariusze wcześniej wypełniane przez osobę badaną zawierają między innymi pytania o takie wartości jak moralność czy o postawy altruistyczne wobec ludzi i zachowań altruistycznych. Podmiot, odpowiadając na pytania kwestionariusza, zastanawia się nad tym, jaki jest, a tym samym przeszukuje w pamięci zdarzenia, które pozwalają mu znaleźć na te pytania odpowiedzi. W konsekwencji: zaczyna spostrzegać siebie na przykład jako „niezbyt altruistyczny” czy „przeważnie uczciwy”. Zgodnie z przyjętym przez badacza schematem eksperymentu podmiot ma następnie podjąć decyzję o zachowaniu (czy też zastanawia się, jak by się zachował). Dostępność psychiczna udzielanych właśnie odpowiedzi na pytania kwestionariusza oczywiście wpłynie teraz na ten, kluczowy, etap eksperymentu. Pojawia się zatem istotne pytanie, czy aby zaobserwowane wyniki nie pojawiły się wyłącznie dlatego, że eksperymentator poprosił wcześniej osobę badana 
o wypełnienie kwestionariusza samoopisu. Inaczej mówiąc, czy nie jest tak, że to wyłącznie treść kwestionariusza każe osobie badanej zastanowić się między innymi nad tym, czy jest altruistyczna lub uczciwa, a potem zachować się w określony sposób. Być może, gdyby osoba badana nie wypełniała tego kwestionariusza, nie zastanawiałaby się nad tym, jaka jest, a tym samym nie zachowała się chwilę później zgodnie z tą konstatacją. Inaczej mówiąc, może być tak, że to nie (jak zakłada eksperymentator) dana mierzona cecha, postawa czy wartość wpływa na zachowanie podmiotu, ale jedynie chwilowa i wywołana w niezamierzony sposób przez eksperymentatora koncentracja podmiotu na określonych treściach to czyni.

Jeśli więc wprowadzamy do schematu eksperymentalnego mediatory i moderatory, to powinniśmy mieć też w schemacie takie warunki, w których tych elementów nie ma (badani nie wypełniają żadnych kwestionariuszy)! I dopiero jeśli okaże się, że wpływ zmiennej niezależnej na zależną jest taki sam w warunkach braku pomiarów mediatorów i moderatorów, jak i w warunkach obecności tego elementu, możemy odrzucić tezę, że tylko sam fakt wypełnienia przez badanych odpowiedniego kwestionariusza wpływał na ich zachowania. Wydawałoby się to dość oczywiste. Tyle, że... tak się jednak w psychologii społecznej nie czyni.

Chciałbym być dobrze zrozumiany. Nie kwestionuję w najmniejszym nawet stopniu potrzeby badań innych aspektów funkcjonowania człowieka niż realne zachowania. Nie mam najmniejszych wątpliwości, że psychologia społeczna powinna badać postawy, stereotypy, zawartość i funkcje struktury „ja”, zgeneralizowane przekonania na temat świata społecznego czy wartości. O zachowaniach psychologia nie musi też wnioskować bezpośrednio. Spadek wagi o 10 kilogramów w ciągu miesiąca może być równie dobrym wskaźnikiem odchudzania się, jak obserwacja, że osoba badana przestała się objadać, niższa kwota na rachunkach za prąd będzie świetnym wskaźnikiem oszczędzania energii. Badając altruizm, nie musimy widzieć, że badany właśnie wpłaca określoną kwotę na cel charytatywny. Wystarczy, jeśli stwierdzimy, że taki przelew bankowy został przez niego dokonany.

Do takiej psychologii, w której musi się znaleźć miejsce nie tylko na eksplorowanie tego, co, jak i po co ludzie myślą, ale też na to, co, dlaczego i po co ludzie robią, tęsknię. Taka właśnie psychologia sprawiła bowiem, że się nią przed laty zainteresowałem. Teraz jest inna, moim zdaniem uboższa i jednostronna. Czy jest z tej sytuacji realne wyjście? Nie wiem... 


\section{Literatura}

Baumeister, R.F., Vohs, K.D., Funder, D.C. (2007). Psychology as the science of selfreports and finger movements: Whatever happened to actual behavior? Perspectives on Psychological Science, 2, 396-403. DOI: 10.1111/j.1745-6916.2007.00051.x.

Deutsche Bank. Raport Finansowy Polaków 2014. Plany na 2015 rok, https://www. deutschebank.pl/raport-portret-finansowy-polakow-2014.pdf, dostęp: 14.05.2020.

Doliński, D. (2018a). Is psychology still a science of behaviour? Social Psychological Bulletin, 13, Article e25025. DOI: 10.5964/spb.v13i2.5205.

Doliński, D. (2018b). Social psychology should be a science of feelings, thoughts and behaviour. Social Psychological Bulletin, 13, Article e26133. DOI:10.5964/spb. v13i2.26133.

Grzyb, T. (2016). Why can't we just ask? The influence of research methods on results. The case of "bystander effect". Polish Psychological Bulletin, 47, 276-283. DOI: 10.1515/ppb-2016-0027

Grzyb, T., Doliński, D. (2017). Beliefs about obedience levels in studies conducted within the Milgram paradigm: Better than average effect and comparisons of typical behaviors by residents of different countries. Frontiers in Psychology, 8, 1632. DOI: 10.3389/ fpsyg.2017.01632.

Heisenberg, W. (1927). Ueber den anschaulichen Inhalt der quantentheoretischen Kinematik and Mechanik. Zeitschrift für Physik, 43, 172-198.

Kaplan, H.R. (1987). Lottery winners: The myth and reality. Journal of Gambling Behavior, 3, 168-178.

Milgram, S. (1974). Obedience to Authority: An Experimental View. New York: Harper and Row.

Motyl, M., et al. (2017). The state of social and personality science: Rotten to the core, not so bad, getting better, or getting worse. Journal of Personality and Social Psychology, 113, 34-58. DOI: 10.1037/pspa0000084.

Peng, K., Nisbett, R.E., Wong, N.Y.C. (1997). Validity problems comparing values across cultures and possible solutions. Psychological Methods, 2, 329-344. 